\title{
Firibastat, the first-in-class brain aminopeptidase a inhibitor, in the management of hypertension: a review of clinical trials
}

\author{
Sara Abdulrahman Alomar', Sarah Ali Alghabban' ${ }^{1}$, Hadeel Abdulaziz Alharbi ${ }^{1}$, Mehad Fahad Almoqati ${ }^{2}$, Yazid Alduraibi ${ }^{1}$, \\ Ahmed Abu-Zaid ${ }^{1,3}$ \\ ${ }^{1}$ College of Medicine, Alfaisal University, Riyadh, Saudi Arabia, ${ }^{2}$ College of Medicine, Taif University, Taif, Saudi Arabia, ${ }^{3}$ College of Graduate \\ Health Sciences, University of Tennessee Health Science Center, Memphis, Tennessee, United States
}

\begin{tabular}{|c|}
\hline Access this article online \\
\hline Website: www.avicennajmed.com \\
\hline DOI: 10.4103/ajm.ajm_117_20 \\
\hline Quick Response Code: \\
\hline
\end{tabular}

\begin{abstract}
An unfortunate subset of hypertensive patients develops resistant hypertension in which optimal doses of three or more first-line antihypertensive drugs fail to sufficiently control blood pressure. Patients with resistant hypertension represent a high-risk and difficult-to-treat group, and such patients are at amplified jeopardies for substantial hypertension-related multi-organ failure, morbidity, and mortality. Thus, there is a pressing requirement to better improve blood pressure control through the pharmaceutical generation of novel classes of antihypertensive drugs that act on newer and alternative therapeutic targets. The hyperactivity of the brain renin-angiotensin system (RAS) has been shown to play a role in the pathogenesis of hypertension in various experimental and genetic hypertensive animal models. In the brain, angiotensin-II is metabolized to angiotensin-III by aminopeptidase A (APA), a membrane-bound zinc metalloprotease enzyme. A large body of evidence has previously established that angiotensin-III is one of the main effector peptides of the brain RAS. Angiotensin-III exerts central stimulatory regulation over blood pressure through several proposed mechanisms. Accumulating evidence from preclinical studies demonstrated that the centrally acting APA inhibitor prodrugs (firibastat and NI956) are very safe and effective at reducing blood pressure in various hypertensive animal models. The primary purpose of this study is to narratively review the published phase I-II literature on the safety and efficacy of APA inhibitors in the management of patients with hypertension. Moreover, a summary of ongoing clinical trials and future perspectives are presented.
\end{abstract}

Key words: Angiotensin III, blood pressure, brain aminopeptidase a, brain renin-angiotensin system, firibastat, hypertension

\section{INTRODUCTION}

Hypertension is a considerable risk factor implicated in cardiovascular and non-cardiovascular disorders, such as coronary artery disease, stroke, heart failure, and renal failure. ${ }^{[1,2]}$ Hypertension is estimated to affect nearly onethird of the adult population in the United States, and its prevalence is highly anticipated to increase over time. ${ }^{[2]}$ Numerous classes of antihypertensive medications are currently available in the market to control blood pressure.

Address for correspondence: Dr. Ahmed Abu-Zaid,

College of Graduate Health Sciences,

University of Tennessee Health Science Center,

Memphis, Tennessee, United States.

E-mail: aabuzaid@live.com
Such classes generally include systemic renin-angiotensin system (RAS) blockers, beta-blockers, calcium-channel blockers, and diuretics. Nevertheless, in spite of the wideranging availability of antihypertensive agents, hypertension

This is an open access journal, and articles are distributed under the terms of the Creative Commons Attribution-NonCommercial-ShareAlike 4.0 License, which allows others to remix, tweak, and build upon the work non-commercially, as long as appropriate credit is given and the new creations are licensed under the identical terms.

For reprints contact: reprints@ @medknow.com

Cite this article as: Alomar SA, Alghabban SA, Alharbi HA, Almoqati MF, Alduraibi Y, Abu-Zaid A. Firibastat, the first-in-class brain aminopeptidase a inhibitor, in the management of hypertension: A review of clinical trials. Avicenna J Med 2021;11:1-7. 
remains poorly controlled in a subset of patients. ${ }^{[2,3]}$ Singleagent antihypertensive medication is not effective in more than one-half of the hypertensive adult population in the United States, and the vast majority of patients necessitate at least two or more antihypertensive medications to adequately control their blood pressure. ${ }^{[2,3]}$ An unfortunate subset of hypertensive patients (roughly 9\%-19\%) develop resistant hypertension in which optimal doses of three or more first-line antihypertensive drugs fail to sufficiently control blood pressure. ${ }^{[4,5]}$ These first-line drugs generally comprise a systemic RAS blocker (either an angiotensin receptor blocker (ARB) or angiotensin-converting enzyme (ACE) inhibitor), a long-acting calcium-channel blocker, and a diuretic. Patients with resistant hypertension represent a high-risk and difficult-to-treat group, and such patients are at amplified jeopardies for substantial hypertension-related multiorgan failure, morbidity, and mortality. ${ }^{[5]}$ Thus, there is a pressing requirement to better improve blood pressure control through the pharmaceutical generation of novel classes of antihypertensive drugs that act on newer and alternative therapeutic targets. ${ }^{[6]}$

The hyperactivity of the brain RAS has been shown to play a key role in the pathogenesis of hypertension in various experimental and genetic hypertensive animal models. ${ }^{[7-9]}$ Such animal models included spontaneously hypertensive rats (SHRs, a model of essential hypertension that is sensitive to systemic RAS blockade), ${ }^{[7]}$ deoxycorticosterone acetate (DOCA)-salt hypertensive rats (a model of reninindependent hypertension that is not sensitive to systemic RAS blockade ${ }^{[8]}$ and transgenic mice overexpressing human angiotensinogen and renin genes. ${ }^{[9]}$ Accumulating evidence established that a functional RAS is present in the brain, including its precursors, enzymes, and receptors. ${ }^{[10-12]}$ Figure 1 depicts the basic metabolic steps implicated in the metabolism of angiotensinogen to angiotensin-III and angiotensin-IV in the brain. In brief, angiotensinII is metabolized to angiotensin-III by aminopeptidase A (APA), a membrane-bound zinc metalloprotease. ${ }^{[13]}$ Angiotensin-II and angiotensin-III are two of the active peptides of the brain RAS, and both ligands exhibit equal

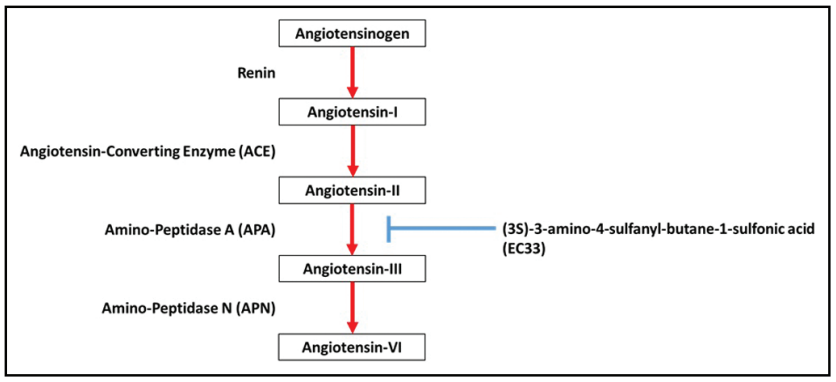

Figure 1: The basic metabolic steps implicated in the metabolism of angiotensinogen to angiotensin-III and angiotensin-IV in the brain binding affinities for angiotensin type-one and typetwo receptors. ${ }^{[10,14]}$ Angiotensin-II and angiotensin-III intracerebroventricularly injected increase blood pressure through three proposed mechanisms: (i) synaptic inhibition of the baroreflex in the tractus solitarius nucleus, (ii) hyperactivity of the sympathetic nervous system, and (iii) the release of arginine-vasopressin (AVP) into the bloodstream. ${ }^{[15]}$ Several studies have previously suggested that the physiologically relevant peptide in the brain RAS responsible for the regulation of blood pressure is angiotensin-III rather than angiotensin-II. ${ }^{[16-18]}$

However, the definitive proof was given by the following experiments. This began with the design and synthesis of the first specific and selective APA inhibitor EC33 ((S)3-amino-4-mercapto-butyl sulfonic acid) and the APN inhibitors (EC27, 2-amino-pentan-1,5-dithiol, and PC18, 2-amino-4-methylsulfonyl butane thiol). ${ }^{[13,19,20]}$ Then by using in vivo these inhibitors, Zini et al. ${ }^{[13]}$ provided the first demonstration that APA generates brain angiotensin-III from angiotensin-II, whereas APN metabolizes angiotensinIII into angiotensin-IV. Subsequently by blocking in vivo each of these metabolic pathways with APA and APN inhibitors, it was possible to determine the respective roles of angiotensin-II and angiotensin-III in the central control of blood pressure and vasopressin release, and to conclude that angiotensin-III is one of the main effector peptides of the brain RAS exerting a tonic stimulatory action on the control of blood pressure and vasopressin release..$^{[13,21-24]}$

Thus, selective inhibition of brain angiotensin-III formation with an APA inhibitor is a one potential mechanism to reduce blood pressure in hypertensive patients. However, a direct exogenous administration of EC33, orally or systemically, does not penetrate the blood-brain barrier. ${ }^{[21,22]}$ Firibastat (originally named RB150, also known as QGC001) and NI956 (also known as QGC006) are the only two available oral prodrugs of the specific and selective brain APA inhibitors, EC33 and NI929, respectively. ${ }^{[25,26]}$ Mechanistically, these prodrugs are administered orally and capable of crossing the blood-brain barrier, whereby the disulfide bridges are cleaved off by brain reductases to produce two active molecules of EC33 and NI929. Afterward, the EC33 and the NI929 molecules inhibit the brain APA activity, block the formation of brain angiotensin-III, decrease the release of AVP into the bloodstream and reduce the mean arterial blood pressure. ${ }^{[22,25-29]}$ Accumulating evidence from preclinical studies demonstrated that brain APA inhibitor prodrugs (firibastat and NI956) are very safe and effective at reducing blood pressure in various hypertensive animal models. ${ }^{[21,22,27,28,30]}$ Two studies investigated the efficacy of firibastat and NI956 in Wistar Kyoto (WKY) normotensive 
and DOCA-salt hypertensive rats. ${ }^{[25,26,29]}$ Both studies reported that the administration of brain APA inhibitors resulted in decreased brain APA activity, decreased mean arterial blood pressure, decreased plasma AVP levels, increased natriuresis, increased diuresis, unchanged heart rate, and unchanged plasma electrolyte (sodium and potassium) levels in the DOCA-salt hypertensive rats. Conversely, none of the abovementioned parameters were affected in the WKY normotensive rats. All in all, these data suggested that APA inhibition might constitute a novel alternative therapeutic approach in the management of patients with hypertension.

Therefore, the primary purpose of this study was to narratively review the available phase I-II literature on the safety and efficacy of centrally acting APA inhibitor prodrugs in the management of patients with hypertension.

\section{MATERIALS AND METHODS}

The PubMed database was screened from January 1st, 2000 to March 15th, 2019. The following keywords were used in the literature search: "firibastat" OR "QGC001" OR "QGC006” OR “RB150" OR “NI956." Additional references from published articles were also manually screened for potential inclusion in the study review. The study inclusion criteria included: (i) studies published in the English language, (ii) patients diagnosed with hypertension, (iii) studies reporting published phase I-III trials in humans, and (iv) studies reporting the efficacy and/or safety of APA inhibitor prodrugs. For each study included in the review, the following details (whenever available) were reported: year of publication, the first author, clinical trial type, clinical trial identification number, study sample size, study design, efficacy, safety, pharmacokinetics, pharmacodynamics, clinical benefits, and conclusions.

\section{RESULTS}

In 2014, Balavoine et al. ${ }^{[31]}$ (NCT01900171, a phase I double-blind, placebo-controlled, and dose-escalating trial) examined the safety, pharmacokinetics, and pharmacodynamics of firibastat in 56 normotensive male Caucasian healthy volunteers. The volunteers were divided into two groups. Group A (interventional group, $n=42$ ) received, in fasting conditions, single oral doses of firibastat $(10,50,125,250,500,750,1,000$, and 1,250 mg). Group B (placebo group, $n=14$ ) received, in fasting conditions, single oral doses of placebo. The randomized assignment ratio of Group A to Group B was 3:1. For firibastat concentrations of 10 and $50 \mathrm{mg}$, there were two and one volunteer(s) in Group A and Group B, respectively. For the remaining of firibastat concentrations, there were six and two volunteers in Group A and Group B, respectively. Twenty-four hours after administration of the dose, blood and urine samples were collected whereas blood pressure was measured regularly throughout. With regard to safety profile, all doses of firibastat were well-endured. Additionally, no major drug-related side effects were observed; only one volunteer in Group A (500 mg dose of firibastat) experienced a treatment-related adverse event of asymptomatic orthostatic hypotension, which started $6 \mathrm{~h}$ after the dose and lasted for $18 \mathrm{~h}$. With regard to pharmacokinetics, the peak plasma concentrations of firibastat and EC33 increased in a dosedependent manner, and the median durations to reach the peak plasma concentrations of firibastat and EC33 were 1.5 and $3 \mathrm{~h}$, respectively. The urinary clearance of both firibastat and EC33 was minimal (less than $2 \%$ of the administered dose). With regard to pharmacodynamics, when compared to placebo, firibastat did not substantially derange the systemic RAS parameters, namely: plasma renin concentration, plasma/urine aldosterone levels, and plasma/ urine cortisone levels. Moreover, firibastat did not markedly alter the vitals-related hemodynamics, namely: heart rate, supine systolic blood pressure and diastolic blood pressure. The study concluded that single oral administration of firibastat (up to $1250 \mathrm{mg}$ ) in normotensive participants was well-endured and free of major drug-related adverse events. Moreover, firibastat did not have significant effects on the systemic RAS biochemical parameters or vitalsrelated hemodynamic parameters. All in all, the study encouraged the experimentation of firibastat in patients with hypertension.

In 2019, Azizi et al. ${ }^{[32]}$ (NCT02322450, a phase IIa multicenter, randomized, double-blind, placebocontrolled, and crossover trial) assessed the safety, efficacy, and pharmacodynamics of firibastat in 34 patients with essential hypertension. After 2 weeks of cessation of current antihypertensive drugs and 2 weeks of run-in interval on placebo, patients with daytime systolic blood pressure of 135-170 $\mathrm{mm} \mathrm{Hg}$ and diastolic blood pressure of 85-105 mm $\mathrm{Hg}$ were enrolled in the study. Patients were randomized in one-to-one ratio into two groups. Group A $(n=17)$ received firibastat for 4 weeks $(250 \mathrm{mg}$ BID for 1 week and upgraded to $500 \mathrm{mg}$ BID for 3 weeks) followed by placebo for 4 weeks. Group B $(n=17)$ received placebo for 4 weeks followed by firibastat for 4 weeks ( $250 \mathrm{mg}$ BID for 1 week and upgraded to $500 \mathrm{mg}$ BID for 3 weeks). In both groups, there was a period of 2 weeks of drug washout between the crossovers. At 4 weeks posttreatment, the daytime ambulatory systolic blood pressure was reduced by $2.7 \mathrm{~mm}$ $\mathrm{Hg}$ with firibastat versus placebo, despite the difference was not statistically significant $(P=0.157)$. Also, the office 
systolic blood pressure was reduced by $4.7 \mathrm{~mm} \mathrm{Hg}$ with firibastat versus placebo, despite the difference was not statistically significant $(P=0.151)$. Firibastat treatment did not affect the nighttime ambulatory blood pressure or the 24-h ambulatory blood pressure. In a multilinear regression analysis, only firibastat treatment $(P=0.0643)$ and baseline daytime ambulatory systolic blood pressure $(P=0.0135)$ were significantly correlated with post-treatment reductions in the daytime ambulatory systolic blood pressure. The more the baseline daytime ambulatory systolic blood pressure was increased, the more the firibastat-mediated blood pressure reduction was noticeable. From the perspective of hormonal effects, firibastat treatment did not alter the plasma levels of systemic RAAS (renin and aldosterone), AVP release (copeptin and apelin), and cortisol. Similarly, urine hormone levels were not affected. Firibastat was largely well-tolerated; only three patients had serious firibastat-related major adverse events, as follow: rash with facial edema which was successfully reversed with an anti-histamine therapy $(n=1)$, transient vestibular disturbance lasting less than $24 \mathrm{~h}(n=1)$, and moderate arthralgia $(n=1)$. The study concluded that a 4-week regimen of firibastat was safe and clinically effective at reducing systolic blood pressure in patients with essential hypertension. Moreover, firibastat did not induce changes on plasma or urine levels of the systemic RAS parameters. Lastly, the study called for a more powered trial with a largesized sample size, longer treatment interval and hypertensive patients with a basal systolic blood pressure superior to $148 \mathrm{~mm} \mathrm{Hg}$ to thoroughly evaluate the tolerability and clinical benefits of firibastat in patients with hypertension.

In 2019, Ferdinand et al. ${ }^{[33]}$ (NCT03198793, a phase II multicenter, open-label, and dose-titrating trial) evaluated the safety, efficacy, and pharmacodynamics of firibastat in 256 overweight or obese patients with hypertension (systolic blood pressure of 135-170 mm Hg and diastolic blood pressure of 85-105 mm Hg) Multiple ethnic groups were enrolled in this study. The proportions of patients who were obese, black, and diabetic comprised $64.8 \%, 38.3 \%$, and $28.5 \%$, respectively. After 2 weeks of cessation of present antihypertensive drugs (washout period), patients received firibastat for a total duration of 8 weeks. The precise regimen protocol was $250 \mathrm{mg}$ BID orally for 2 weeks followed by $500 \mathrm{mg}$ BID for 6 weeks if automated office blood pressure was $\geq 140 / 90 \mathrm{~mm} \mathrm{Hg}$; hydrochlorothiazide $25 \mathrm{mg}$ QD was supplemented after 4 weeks till the end of the study only if automated office blood pressure was $\geq 160 / 110 \mathrm{~mm} \mathrm{Hg}$. Only $15 \%$ of patients required addition of hydrochlorothiazide as an add-on drug during the study. Firibastat treatment significantly reduced the systolic and diastolic automated office blood pressure by $9.5 \mathrm{~mm} \mathrm{Hg}(P<0.0001)$ and $4.2 \mathrm{~mm}$ $\mathrm{Hg}(P<0.0001)$, respectively. In addition, firibastat treatment substantially decreased the 24-h ambulatory systolic and diastolic blood pressure by $2.7 \mathrm{~mm} \mathrm{Hg}(P=0.002)$ and $1.4 \mathrm{~mm} \mathrm{Hg}(P=0.01)$, respectively. Remarkable decrease in blood pressure was observed in all patients irrespective of demographical (age, gender, and body mass index) or renal (estimated glomerular filtration rate) parameters. Moreover, subgroup analysis by race demonstrated that firibastat treatment was equally effective in reducing systolic automated office blood pressure in black $(-10.5 \pm$ $14.7 \mathrm{~mm} \mathrm{Hg} ; P<0.0001)$ and non-black $(-8.9 \pm 14.1 \mathrm{~mm} \mathrm{Hg}$, $P<0.0001)$ hypertensive patients. Firibastat treatment did not substantially alter the glucose, creatinine, and electrolyte (sodium and potassium) levels (all $P>0.05$ ). The safety profile was largely endurable. Treatment-related side effects occurred in 36 patients (14.1\%), and the two most frequently reported ones comprised headache $(n=11,4.3 \%)$ and skin rash $(n=8,3.1 \%)$. Nineteen patients $(7.5 \%)$ experienced adverse events that led to firibastat termination. Only one patient $(0.4 \%)$ experienced a serious side effect of erythema multiforme. No mortality occurred during the study. The study concluded that firibastat was tolerable and effective clinically at reducing the blood pressure in a high-risk group of patients with hypertension.

\section{DISCUSSION}

Table 1 summarizes the published phase I-II trials of firibastat in the management of patients with hypertension. Overall, these studies demonstrated that firibastat was safe and clinically effective at reducing blood pressure in hypertensive patients without impacting the systemic RAS parameters or vital signs. However, this conclusion should be interpreted with caution in light of its limitations. Such limitations include the low number of published phase II clinical trials $(n=2)$, small sample size of patients, and lack of head-to-head comparison of firibastat with the standard-of-care antihypertensive drugs. Importantly, there is a registered phase III clinical trial (ClinicalTrials. gov Identifier: NCT04277884) that will examine the safety and efficacy of firibastat versus placebo in 502 patients with difficult-to-treat or resistant hypertension.

Earlier studies demonstrated that the brain RAS is implicated in the progression of cardiac dysfunction as well as heart failure in settings of post-myocardial infarction. ${ }^{[34-36]}$ Preclinical studies utilizing animal models of heart failure post-MI in rats ${ }^{[37,38]}$ and mice ${ }^{[39]}$ showed that oral administration of APA inhibitor prodrug (firibastat) substantially attenuated the development of post-myocardial infarction aftermaths of cardiac dysfunction and heart failure. To explore this in human subjects, there is an ongoing phase II clinical trial (ClinicalTrials.gov Identifier: 
Table I: Summary of the published phase I-II trials of firibastat in the management of patients with hypertension

\begin{tabular}{llllll}
\hline $\begin{array}{l}\text { First } \\
\text { author, }\end{array}$ & Year Phase NCT Patients n Regimen & \\
[Ref] & & &
\end{tabular}

Balavoine 2014 I NCT01900I7I Normotensive 42 Firibastat The study examined the safety, pharmacokinetics and pharmacodynamics of et al., ${ }^{[31]}$

14 Placebo No major firibastat-related side effects were observed; only one patient $(n=1)$ developed asymptomatic orthostatic hypotension.

The median durations to reach the peak plasma concertations of firibastat and $\mathrm{EC} 33$ were 1.5 and $3 \mathrm{~h}$, respectively.

The urinary clearance of firibastat and EC33 was minimal $(<2 \%$ of the administered dose).

Firibastat did not affect the plasma/urine levels of renin, aldosterone and cortisone.

$\begin{array}{llllll}\begin{array}{l}\text { Azizi } \\ \text { et al., }{ }^{[32]}\end{array} & 2019 \quad \text { II } & \text { NCT02322450 } & \text { Hypertensive } & 17 & \text { Firibastat } \\ & & & 17 & \text { Placebo }\end{array}$

Firibastat did not affect heart rate, systolic BP or diastolic BP.

Azizi 2019 II NCT02322450 Hypertensive 17 Firibastat The study assessed the safety, efficacy and pharmacodynamics of a 4-week treatment of firibastat.

Three patients treated with firibastat had major adverse events (rash with facial edema, transient vestibular disturbance and moderate arthralgia). At 4-week post-treatment, daytime ambulatory systolic BP was reduced by $2.7 \mathrm{~mm} \mathrm{Hg}$ with firibastat versus placebo $(P=0.157)$.

At 4-week post-treatment, office systolic BP was reduced by $4.7 \mathrm{~mm} \mathrm{Hg}$ with firibastat versus placebo $(P=0.15 \mathrm{I})$.

In a multilinear regression analysis, the more the baseline daytime ambulatory systolic BP was increased, the more the firibastat-mediated BP reduction was noticeable.

Firibastat did not affect 24-h ambulatory BP.

Firibastat did not affect plasma levels of renin, aldosterone, copeptin, apelin and cortisol. $\begin{array}{lllll}\begin{array}{l}\text { Ferdinand } 2019 \text { II NCT03198793 } \\ \text { et al.,. }{ }^{[33]}\end{array} & \begin{array}{l}\text { Hypertensive } 256 \text { Firibastat } \\ \text { (overweight }\end{array} & \begin{array}{l}\text { The study evaluated the safety, efficacy and pharmacodynamics of an } \\ \text { 8-week treatment of firibastat. }\end{array}\end{array}$

Hydrochlorothiazide was added after four weeks till the end of the study only if automated office BP was $\geq 160 / 110 \mathrm{~mm} \mathrm{Hg}$.

Nineteen patients $(7.5 \%)$ experienced adverse events that led to firibastat termination. Only one patient $(0.4 \%)$ experienced a serious side effect of erythema multiforme.

Firibastat treatment reduced systolic and diastolic automatic office BP by 9.5 and $4.2 \mathrm{~mm} \mathrm{Hg}(P<0.000 \mathrm{I})$.

Firibastat reduced the 24-h ambulatory systolic and diastolic BP by 2.7 and $1.4 \mathrm{~mm} \mathrm{Hg}$, respectively $(P=0.002$ and $P=0.01$, respectively).

Firibastat did not affect the plasma levels of glucose, creatinine, sodium or potassium.

Firibastat treatment was not affected by the estimated glomerular filtration rate.

$\mathrm{BP}=$ blood pressure, $\mathrm{EC} 33=(3 \mathrm{~S})$-3-amino-4-sulfanyl-butane- $\mathrm{I}$-sulfonic acid, $\mathrm{mm} \mathrm{Hg}=$ millimeter of mercury, $n=$ sample size, $\mathrm{NCT}=$ national clinical trial, $\mathrm{Ref}=$ reference

NCT03715998) that will compare the safety and efficacy of firibastat versus ACE inhibitor ramipril in preventing left ventricular dysfunction in patients with acute myocardial infarction. Table 2 summarizes all registered clinical trials of firibastat in the management of patients with hypertension and heart failure post-MI.

Firibastat is the first-in-class centrally acting APA inhibitor prodrug of EC33. ${ }^{[22]}$ In 2019, Keck et al. ${ }^{[25]}$ reported the development of NI956 (also known as QGC006), a new centrally acting brain APA inhibitor prodrug of NI929. The authors showed that NI929 was ten times more potent and efficient than EC33 at inhibiting brain APA enzymatic activity in vitro and in vivo in DOCA-salt hypertensive rats. Overall, NI956 given by oral route, entered the brain where it was reduced, generating two active molecules of
NI929, that substantially normalized brain APA activity, reduced blood pressure, reduced plasma AVP release and increased diuresis/natriuresis in DOCA-salt hypertensive rats. NI956 did not impact the plasma electrolyte levels of sodium and potassium in the DOCA-salt hypertensive rats. More importantly, the vitals and hormonal levels were not impacted in the control normotensive WKY rats. The authors concluded that NI956 is the best-in-class centrally acting brain APA inhibitor prodrug. However, this drug has not yet been tested in human phase I-III clinical trials.

\section{CONCLUSION}

Firibastat is the first-in-class centrally acting APA inhibitor prodrug. Pharmacologically, firibastat prevents the conversion of angiotensin-II to angiotensin-III, one of the 
Alomar, et al:: Firibastat in the management of hypertension

\begin{tabular}{|c|c|c|c|}
\hline NCT, [ref] & Phase & Title & Status \\
\hline NCT0I $900184,{ }^{[40]}$ & 1 & $\begin{array}{l}\text { Part I: Safety, Tolerability, Pharmacokinetics and Pharmacodynamics Ascending Single Dose and Food } \\
\text { Influence Study of QGC00I Administered Orally To Healthy Adult Subjects, Part 2: Safety, Tolerability, } \\
\text { Pharmacokinetics and Pharmacodynamics Ascending Multiple Dose Study of QGC00I Administered } \\
\text { Orally To Healthy Adult Subjects. }\end{array}$ & $\begin{array}{l}\text { Completed, not } \\
\text { published }\end{array}$ \\
\hline NCT037I4685,[41] & 1 & $\begin{array}{l}\text { A Study in Healthy Subjects Designed to Evaluate the Pharmacokinetic Profile of Firibastat } \\
\text { (QGCOOI) and Active Metabolites Following Administration of Firibastat (QGCOOI) Prototype Tablet } \\
\text { Formulations }\end{array}$ & $\begin{array}{l}\text { Completed, not } \\
\text { published }\end{array}$ \\
\hline NCT02780I80,[42] & II & $\begin{array}{l}\text { A Randomized, Double-blind, Multi-centre Study to Assess Safety and Efficacy of Incremental Doses } \\
\text { of QGC00I in Patients With New York Heart Association (NYHA) Class II/III Chronic Heart Failure } \\
\text { (HF) With Left Ventricular Systolic Dysfunction Versus Placebo }\end{array}$ & $\begin{array}{l}\text { Terminated } \\
\text { (insufficient } \\
\text { recruitment) }\end{array}$ \\
\hline NCT037I5998, ${ }^{[43]}$ & II & $\begin{array}{l}\text { A Phase 2, Double-blind, Active-controlled, Dose-titrating Efficacy and Safety Study of Firibastat } \\
\text { Compared to Ramipril Administered Orally, Twice Daily, Over I } 2 \text { Weeks to Prevent Left Ventricular } \\
\text { Dysfunction After Acute Myocardial Infarction }\end{array}$ & Recruiting \\
\hline NCT04277884,[44] & III & $\begin{array}{l}\text { A Phase 3, Double-blind, Placebo-controlled, Efficacy and Safety Study of Firibastat (QGC00I) } \\
\text { Administered Orally, Twice Daily, Over I2 Weeks in Difficult-to-treat/Resistant Hypertensive Subjects }\end{array}$ & Not yet recruiting \\
\hline
\end{tabular}

main effector peptides of the brain RAS that exerts central stimulatory regulation over blood pressure. Preclinical studies in various hypertensive animal models demonstrated the safety and clinical efficacy of firibastat in improving blood pressure control. These conclusions were also reciprocated in human phase I-II clinical trials, highlighting that firibastat may constitute a potential alternative therapy in the management of high-risk patients with difficult-totreat or resistant hypertension. Nevertheless, the safety and efficacy of firibastat should be further solidified in patients with hypertension through the design of multicentric, randomized, large-sized, and highly powered phase III clinical trials.

\section{Financial support and sponsorship}

Nil.

\section{Conflicts of interest}

There are no conflicts of interest.

\section{References}

1. Collaborators GRF. Global, regional, and national comparative risk assessment of 84 behavioural, environmental and occupational, and metabolic risks or clusters of risks for 195 countries and territories, 1990-2017: A systematic analysis for the Global Burden of Disease Study 2017. Lancet 2018;392:1923-94.

2. Benjamin EJ, Muntner P, Alonso A, Bittencourt MS, Callaway CW, Carson AP, et al.; American Heart Association Council on Epidemiology and Prevention Statistics Committee and Stroke Statistics Subcommittee. Heart disease and stroke statistics-2019 update: A report from the American Heart Association. Circulation 2019;139:e56-e528.

3. Nguyen Q, Dominguez J, Nguyen L, Gullapalli N. Hypertension management: An update. Am Health Drug Benefits 2010;3:47-56.

4. Doroszko A, Janus A, Szahidewicz-Krupska E, Mazur G, Derkacz A. Resistant hypertension. Adv Clin Exp Med 2016;25:173-83.

5. Carey RM, Calhoun DA, Bakris GL, Brook RD, Daugherty SL, DennisonHimmelfarb CR, et al.; American Heart Association Professional/Public Education and Publications Committee of the Council on Hypertension; Council on Cardiovascular and Stroke Nursing; Council on Clinical
Cardiology; Council on Genomic and Precision Medicine; Council on Peripheral Vascular Disease; Council on Quality of Care and Outcomes Research; and Stroke Council. Resistant hypertension: Detection, evaluation, and management: A scientific statement from the American Heart Association. Hypertension 2018;72:e53-90.

6. Aronow WS. Approaches for the management of resistant hypertension in 2020. Curr Hypertens Rep 2020;22:3.

7. Ganten D, Hermann K, Bayer C, Unger T, Lang RE. Angiotensin synthesis in the brain and increased turnover in hypertensive rats. Science 1983;221:869-71.

8. Basso N, Ruiz P, Mangiarua E, Taquini AC. Renin-like activity in the rat brain during the development of DOC-salt hypertension. Hypertension 1981;3:II-14.

9. Davisson RL, Yang G, Beltz TG, Cassell MD, Johnson AK, Sigmund CD. The brain renin-angiotensin system contributes to the hypertension in mice containing both the human renin and human angiotensinogen transgenes. Circ Res 1998;83:1047-58.

10. Saavedra JM. Brain and pituitary angiotensin. Endocr Rev 1992;13:32980.

11. Xu Q, Jensen DD, Peng H, Feng Y. The critical role of the central nervous system (pro)renin receptor in regulating systemic blood pressure. Pharmacol Ther 2016;164:126-34.

12. Llorens-Cortes C, Touyz RM. Evolution of a new class of antihypertensive drugs: Targeting the brain renin-angiotensin system. Hypertension 2020;75:6-15.

13. Zini S, Fournie-Zaluski MC, Chauvel E, Roques BP, Corvol P, LlorensCortes C. Identification of metabolic pathways of brain angiotensin II and III using specific aminopeptidase inhibitors: Predominant role of angiotensin III in the control of vasopressin release. Proc Natl Acad Sci U S A 1996;93:11968-73.

14. Wright JW, Harding JW. Brain angiotensin receptor subtypes AT1, AT2, and AT4 and their functions. Regul Pept 1995;59:269-95.

15. Keck M, Hmazzou R, Llorens-Cortes C. Orally active aminopeptidase A inhibitor prodrugs: Current state and future directions. Curr Hypertens Rep 2019;21:50.

16. Batt CM, Klein EW, Harding JW, Wright JW. Pressor responses to amastatin, bestatin and plummer's inhibitors are suppressed by pretreatment with the angiotensin receptor antagonist sarthran. Brain Res Bull 1988;21:731-5.

17. Wright JW, Jensen LL, Roberts KA, Sardinia MF, Harding JW. Structurefunction analyses of brain angiotensin control of pressor action in rats. Am J Physiol 1989;257:R1551-7.

18. Wright JW, Mizutani S, Murray CE, Amir HZ, Harding JW. Aminopeptidaseinduced elevations and reductions in blood pressure in the spontaneously hypertensive rat. J Hypertens 1990;8:969-74. 
19. Chauvel EN, Llorens-Cortès C, Coric P, Wilk S, Roques BP, Fournié-Zaluski MC. Differential inhibition of aminopeptidase $\mathrm{A}$ and aminopeptidase $\mathrm{N}$ by new beta-amino thiols. J Med Chem 1994;37:2950-7.

20. Fournié-Zaluski MC, Coric P, Turcaud S, Bruetschy L, Lucas E, Noble F, et al. Potent and systemically active aminopeptidase $\mathrm{N}$ inhibitors designed from active-site investigation. J Med Chem 1992;35:1259-66.

21. Reaux A, Fournie-Zaluski MC, David C, Zini S, Roques BP, Corvol P, et al. Aminopeptidase A inhibitors as potential central antihypertensive agents. Proc Natl Acad Sci U S A 1999;96:13415-20.

22. Fournie-Zaluski MC, Fassot C, Valentin B, Djordjijevic D, ReauxLe Goazigo A, Corvol P, et al. Brain renin-angiotensin system blockade by systemically active aminopeptidase A inhibitors: A potential treatment of salt-dependent hypertension. Proc Natl Acad Sci U S A 2004;101:7775-80.

23. Réaux A, de Mota N, Zini S, Cadel S, Fournié-Zaluski MC, Roques BP, et al. PC18, a specific aminopeptidase $\mathrm{N}$ inhibitor, induces vasopressin release by increasing the half-life of brain angiotensin III. Neuroendocrinology 1999;69:370-6.

24. Zini S, Demassey Y, Fournié-Zaluski MC, Bischoff L, Corvol P, LlorensCortès $\mathrm{C}$, et al. Inhibition of vasopressinergic neurons by central injection of a specific aminopeptidase A inhibitor. Neuroreport 1998;9:825-8.

25. Keck $\mathrm{M}$, De Almeida $\mathrm{H}$, Compère $\mathrm{D}$, Inguimbert $\mathrm{N}$, Flahault $\mathrm{A}$, Balavoine F, et al. NI956/QGC006, a potent orally active, brainpenetrating aminopeptidase $\mathrm{A}$ inhibitor for treating hypertension. Hypertension 2019;73:1300-7.

26. Bodineau L, Frugière A, Marc Y, Inguimbert N, Fassot C, Balavoine F, et al. Orally active aminopeptidase A inhibitors reduce blood pressure: A new strategy for treating hypertension. Hypertension 2008;51:1318-25.

27. Bodineau L, Frugière A, Marc Y, Claperon C, Llorens-Cortes C. Aminopeptidase A inhibitors as centrally acting antihypertensive agents. Heart Fail Rev 2008;13:311-9.

28. Marc Y, Gao J, Balavoine F, Michaud A, Roques BP, Llorens-Cortes C. Central antihypertensive effects of orally active aminopeptidase A inhibitors in spontaneously hypertensive rats. Hypertension 2012;60:411-8.

29. Marc Y, Hmazzou R, Balavoine F, Flahault A, Llorens-Cortes C. Central antihypertensive effects of chronic treatment with RB150: An orally active aminopeptidase $\mathrm{A}$ inhibitor in deoxycorticosterone acetate-salt rats. J Hypertens 2018;36:641-50.

30. Wright JW, Tamura-Myers E, Wilson WL, Roques BP, Llorens-Cortes C, Speth RC, et al. Conversion of brain angiotensin II to angiotensin III is critical for pressor response in rats. Am J Physiol Regul Integr Comp Physiol 2003;284:R725-33.

31. Balavoine F, Azizi M, Bergerot D, De Mota N, Patouret R, Roques BP, et al. Randomised, double-blind, placebo-controlled, dose-escalating phase I study of QGC001, a centrally acting aminopeptidase a inhibitor prodrug. Clin Pharmacokinet 2014;53:385-95.

32. Azizi M, Courand PY, Denolle T, Delsart P, Zhygalina V, Amar L, et al. A pilot double-blind randomized placebo-controlled crossover pharmacodynamic study of the centrally active aminopeptidase A inhibitor, firibastat, in hypertension. J Hypertens 2019;37:1722-8.

33. Ferdinand KC, Balavoine F, Besse B, Black HR, Desbrandes S, Dittrich HC, et al. Efficacy and safety of firibastat, A first-in-class brain aminopeptidase A inhibitor, in hypertensive overweight patients of multiple ethnic origins. Circulation 2019;140:138-46.

34. Zhang ZH, Francis J, Weiss RM, Felder RB. The renin-angiotensinaldosterone system excites hypothalamic paraventricular nucleus neurons in heart failure. Am J Physiol Heart Circ Physiol 2002;283:H423-33.

35. Wang H, Huang BS, Ganten D, Leenen FH. Prevention of sympathetic and cardiac dysfunction after myocardial infarction in transgenic rats deficient in brain angiotensinogen. Circ Res 2004;94:843.

36. Leenen FH. Brain mechanisms contributing to sympathetic hyperactivity and heart failure. Circ Res 2007;101:221-3.

37. Huang BS, Ahmad M, White RA, Marc Y, Llorens-Cortes C, Leenen FH. Inhibition of brain angiotensin III attenuates sympathetic hyperactivity and cardiac dysfunction in rats post-myocardial infarction. Cardiovasc Res 2013;97:424-31.

38. Leenen FHH, Ahmad M, Marc Y, Llorens-Cortes C. Specific inhibition of brain angiotensin III formation as a new strategy for prevention of heart failure after myocardial infarction. J Cardiovasc Pharmacol 2019;73:82-91.

39. Boitard SE, Marc Y, Keck M, Mougenot N, Agbulut O, Balavoine F, et al. Brain renin-angiotensin system blockade with orally active aminopeptidase A inhibitor prevents cardiac dysfunction after myocardial infarction in mice. J Mol Cell Cardiol 2019;127:215-22.

40. Study of the Product QGC001 as a Single Dose and Multiple Doses Administered Orally to Healthy Adult Subjects. 2020. Available from: https://clinicaltrials.gov/ct2/show/NCT01900184. [Last accessed on 2020 May 23].

41. Evaluation of the PK Profile of Firibastat Following Administration of Firibastat Prototype Tablet Formulations. 2020. Available from: https:// clinicaltrials.gov/ct2/show/NCT03714685. [Last accessed on 2020 May 23].

42. QUantum Genomics Incremental Dosing in Heart Failure - QUID-HF (QUID-HF). 2020. Available from: https://clinicaltrials.gov/ct2/show/ NCT02780180. [Last accessed on 2020 May 23].

43. Firibastat or Ramipril After Acute Myocardial Infarction for Prevention of Left Ventricular Dysfunction (QUORUM). 2020. Available from: https://clinicaltrials.gov/ct2/show/NCT03715998. [Last accessed on 2020 May 23].

44. Firibastat in Treatment-resistant Hypertension (FRESH). 2020. Available from: https://clinicaltrials.gov/ct2/show/NCT04277884. [Last accessed on 2020 May 23]. 